\title{
An Attempted Discussion on the Inheritance And Development of Cloisonné
}

\author{
Wanyu Zhang \\ Fashion Institute \\ Sichuan Normal University \\ Chengdu,China \\ 17381225@qq.com \\ Rongbin Wang \\ Fashion Institute \\ Sichuan Normal University \\ Chengdu,China \\ 100093929@qq.com
}

\begin{abstract}
This paper makes some brief analyses and puts forward some problems which exist in the modern inheritance and development of Cloisonné through its origins, history and current situations. It also gives some solving measures according to a series of cases. For example, to control the production cost of Cloisonné crafts according to the market demand, develop the designs of Cloisonné jewelry, and provide Cloisonné masters with preferential policies, to encourage the development of Cloisonné crafts and to exploit the new materials for reducing the costs, etc. It aims to make Cloisonné crafts gain a better inheritance and development opportunity in the modern times.

Key words: Cloisonné; inheritance; development.
\end{abstract}

\section{INTRODUCTION}

The craftsmanship of Cloisonné originates in West Asia, and has been taken as imports in China for a thousand years. With the integration of national culture, it has become an integral part in Chinese culture. However, in today's society, because of its complicated patterns and high prices, Cloisonné has been very difficult to integrate into modern people's lives. Therefore, combining with some specific cases, this paper puts forward some solving measures for the inheritance and development of Cloisonné, in order to make it fit the sense of aesthetic which comes from modern people, and go into the people's lives in today's society, thus achieving the inheritance and development opportunities.

\section{THE CRAFTSMANSHIP AND DEVELOPMENT OF CLOISONNÉ}

Cloisonné, also called "copper padding thread weaving enamel", is a kind of objects which uses the copper wires to filigree and weld according to the mapping patterns on the fetal copper then to fill according to the patterns. Because, initially, blue glaze is used to apply the bottom, it's called Cloisonné.However, as the name of a craftsmanship, Cloisonné has been included in the first batch of national intangible cultural heritage in 2006 because of its complicated craftsmanship and noble status. There are four approaches to make Cloisonné: the fetal copper chisel flowers enamel,

\author{
Yueshan Wang \\ Fashion Institute \\ Sichuan Normal University \\ Chengdu,China \\ 545475063@qq.com \\ *Corresponding author
}

painted enamel, filigree enamel and hammer enamel.

Fetal copper chisel flowers enamel is to carve chisel in fetal copper which has already been drawn with patterns, then to tick the base besides the main lines, after that to glaze in carved patterns, and finally fired, polished and gold-plated; while filigree enamel is to weld a flat thin copper wire to the patterns drawn with fetal copper and then fill in glaze in the patterns, after that, it's fired, polished, ground and plated. The above two kinds of production methods are almost extinct now. Painted enamel was originated in Europe, and was brought in China in the 16th Century, most popular in the Qing dynasty. Its production is to use glaze to apply to the base color and fire and then directly paint on it with glaze, whose color will come out after firing repeatedly for tens to hundreds of times; hammer enamel is generally to embossed the fetal copper according to the drawing patterns in the form of hammering, the convex part is set aside to dot flat all kinds of enamel glaze, and the concave part of the pattern is decorated with gilt, after firing, the ups and downs of itself will leave a sense of three-dimension space and a sense of hierarchy [1].

Table 1: The Characteristics and Changes of colors, patterns, carcass, etc of Cloisonné in Various Periods in History[1-3]

\begin{tabular}{|c|c|c|c|c|}
\hline Times & Carcass & Color of Glaze & Patterns & $\begin{array}{c}\text { Functions of the } \\
\text { utensils }\end{array}$ \\
\hline $\begin{array}{l}\text { Xuande } \\
\text { Years, } \\
\text { Ming } \\
\text { Dynasty }\end{array}$ & \begin{tabular}{|l} 
Gold, \\
copper \\
(thick \\
carcass)
\end{tabular} & $\begin{array}{ll}\text { Sky } & \text { blue, } \\
\text { sapphire } & \text { blue, } \\
\text { light } & \text { green, } \\
\text { green, } & \text { red, } \\
\text { yellow } & \end{array}$ & $\begin{array}{l}\text { Banana leaf, } \\
\text { TaoTie(the } \\
\text { son r of } \\
\text { dragon), lion } \\
\text { play r ball, } \\
\text { passion fruit, } \\
\text { Daming lotus }\end{array}$ & $\begin{array}{l}\text { Bottle, plate, bowl, } \\
\text { furnace, aroma } \\
\text { burner }\end{array}$ \\
\hline $\begin{array}{l}\text { Jingtai } \\
\text { Years, } \\
\text { Ming } \\
\text { Dynasty }\end{array}$ & $\begin{array}{l}\text { Gold, re } \\
\text { d copper }\end{array}$ & $\begin{array}{|lr|}\text { grape } & \text { purple, } \\
\text { turquoise } & \text { blue, } \\
\text { purple, } & \text { chrome } \\
\text { blue, } & \text { Prussian } \\
\text { blue, powder blue }\end{array}$ & $\begin{array}{l}\text { Subjects of } \\
\text { Taoism and } \\
\text { Buddhism } \\
\text { Dragon play } \\
\text { ball, clouds } \\
\text { and flame } \\
\end{array}$ & $\begin{array}{l}\text { The flower pot, } \\
\text { basin, charcoal } \\
\text { brazier, the lamp } \\
\text { stand, bottles, pots, } \\
\text { Ding }\end{array}$ \\
\hline Qing & Copper, & Silver & Celebrities & Screen, the throne, \\
\hline
\end{tabular}




\begin{tabular}{|l|l|l|l|l|}
\hline & $\begin{array}{l}\text { silver, } \\
\text { porcelain } \\
\text { purple }\end{array}$ & $\begin{array}{l}\text { yellow, jade } \\
\text { green, printing } \\
\text { ink and added } \\
\text { glass } \\
\text { (even gold and } \\
\text { silver will join } \\
\text { (thin } \\
\text { carcass) } \\
\text { glaze to enhance } \\
\text { the luxuriance) }\end{array}$ & $\begin{array}{l}\text { dynasties as } \\
\text { the subjects }\end{array}$ & $\begin{array}{l}\text { table, bed, poetic } \\
\text { couplet, toys, } \\
\text { diamond } \\
\text { disk,musical } \\
\text { instruments used } \\
\text { in a Buddhist or } \\
\text { Taoist mass }\end{array}$ \\
\hline $\begin{array}{l}\text { The } \\
\text { Republic } \\
\text { of China }\end{array}$ & $\begin{array}{l}\text { Copper } \\
\text { (thin } \\
\text { carcass) }\end{array}$ & $\begin{array}{l}\text { Colorful and } \\
\text { floating }\end{array}$ & & \\
\hline $\begin{array}{l}\text { Modern } \\
\text { Times }\end{array}$ & Copper & $\begin{array}{l}\text { coral red, red, } \\
\text { green, white, } \\
\text { blue,malachite } \\
\text { green are added }\end{array}$ & & $\begin{array}{l}\text { Stationery, tea set, } \\
\text { wine set, lighting, } \\
\text { accessories etc. }\end{array}$ \\
\hline
\end{tabular}

Because of its gorgeous colors and long history, Cloisonné has a very high artistic and collection value. With the development of Cloisonné in China, its patterns, colors and functions of utensils have made many changes, and it has fit in with the aesthetic standards which come from Chinese people, it has gradually become a part of the essence in traditional Chinese culture.

Zhang Tonglu, the so-called "Shippo Cloisonné and Master Zhang", is also rated a representative heir of the intangible cultural heritage of Cloisonné. Master Zhang has also focused on the research and inheritance of Cloisonné. [4]He not only recovers the cast carcassestechnology after twenty thousand times of firing, but also presides the design and development of Cloisonné in his own "Lu Ying Blue" Glaze Art Co. Ltd., trying to carry out certain innovation under the premise of inheritance. The representative work of Master Zhang is a masterpiece to the 60th anniversary of ChinA-- "Splendid China" with twelve Chinese zodiacs.

Different from the Cloisonné works with only one single zodiac, this piece of work collects all twelve zodiacs together into one utensil, uesd a large area of gilding and inlaied sixty pieces of gems, such as turquoise, agate, petrified wood and others, not sparing labor or money. It can be said to devoted numerous efforts. This work was awarded the "Chinese National Art Treasures”, representing the highest achievement in contemporary China Cloisonné craftsmanship. In addition, the "Twelve Royal Totems", "Live Together Till Old and Grey", "Sweet Peace” and "Rich and Wealth Life" of Master Zhang are all collected in China Taipei the Imperial Palace Museum, and his other works are bided record high in each big auction. The work of "Seismograph" was sold 5000 CNY in 1996, and was auctioned 460,000CNY in 1996 in the Sotheby's auction. However, "Sitting Dragon and Flower Shape Aroma Burner" made in 1970s was auctioned 11million CNY.

The great achievement Master Zhang has made shows that Cloisonné still has the collection value and great development space in morden times. However, as the most valueable heir of the inheritance of Cloisonné, Master Zhang still feels helpless sometimes - due to the high cost of Cloisonne and complicated process, the target customers are mostly those who have high economic cability and appreciation of art works, which is only a small group of people.Thus, the limitations and defferentiations lead to the seperation of public and professional works.

\section{THE PROBLEMS FACING THE INHERITANCE OF CLOISONNÉ}

In the 1980s, with the support from the goverment, the largest domestic Cloisonné factory -- Beijing Arts and Crafts Factory, was in a good condition, domestic and foreign customers came to buy Cloisonné works constantly. However, with the factory staff were poached by foreign enterprises with high salaries, the state no longer does underwriting. After the failure in price war between domestic and foreign Cloisonné manufacturers, Chinese Cloisonné factories were almost extincted. Although there were still some manufacturing factories of Cloisonné in the countryside, the scales were small, and the quality was rough. The inheritance of Cloisonné seemed to be hopeless. As "The First Person of theCloisonné Production", Master Zhang made the determination to save the bleak situation. He convened old colleagues from Beijing Arts and Crafts Factory to set up factories to produce Cloisonné.However the complicated process and high costs made their targets limited to a minority of consumers. Without the support from the government, Master Zhang was left alone with weak power, and he do not have powerful measures. Therefore, as the essence of tradit ional Chinese culture, Cloisonné faces uncountable difficulties during its own development progress.

The writer believes the following are the reasons which cause the problems of the inheritance of Cloisonné

A. The state no longer does underwriting, without its support, it's difficult for manufacturers to find the market. Because natural minerals,precious stones, precious metals are used in the production of Cloisonné, it's destined to be costly. As for the crafts process, the requirements of complicated filigree, dotting blue and firing processes are very strict and labor-costing. These two reasons result in the unacceptable price for the public. Therefore, the target customers are greatly limited.

B. Because of the limitations of the targets, masters are not able to concentrate on the creation and research of Cloisonné, further more, they encounter many obstacles in the inheritance of the crafts. Without adequate financial support, it's easy for craft masters to be stretched in artistic creation, due to the consideration of marketing background. In that case , the artistic value will definitely decrease a lot which is catastrophic to the developmet of Cloisonné.

C. Due to the factors like the cost, sales and other issues, now in Cloisonné production, masters rarely use precious metals such as gold, silver and other precious materials. Also, suitable alternative materials for glaze have not been found yet. Therefore, there is a great gap among Cloisonné handicrafts on the market -- cheap and roughly manufactured works with no collection or aesthetic value; while works with exquisite craftsmanship are so expensive that they are difficult to be accepted by the public.As a result, Cloisonné is getting away from modern people's life.

Cloisonné handicrafts are led into mass production. Currently, most Cloisonné handicrafts are roughly made, lack of innovation and creativity, just blind imitation to classic styles. Complicated patterns and colors are no longer favored, 
instead, concise and fashionable styles are occupying people's aesthetics.Also it's difficult to arouse consumers' desire to buy the crafts with high price and low practicability. As a consequence, it is difficult to integrate Cloisonné handicrafts into modern people's lives.

However, with thousands of years development in China , and the huge development future of Cloisonné, we must consider how to find a way for Cloisonné craftmanship.

\section{THE DEVELOPMENT OF CLOISONNÉ IN WESTERN COUNTRIES AND ITS ENLIGHTMENTS}

As the imported product, Cloisonné also has different developments in some western countries. It has gradually changed to meet the local ethnic culture and aesthetic standard as an art work according to the native culture. For example, the French "painted enamel" and Japanese "Shippo burns", the techniques in these works has not only absorbed foreign elements but also contain new ideas and perfections,in consequence, they formed their unique styles.This integration and innovation have a vital significance for Chinese Cloisonné development.

In western history,Cloisonné is not only applied for containers, but also uesd to make accessories during Renaissance. While in Art Nouveau, it has been even more popular to use Cloisonné in jewelry-making. One of the representatives is Alphonse Mucha (1860 -- 1939). As a symbol of Art Nouveau, Mucha prefers the elegant depictions of Janpanese woodcut art.He also added the magnificent Byzantinism and exquisite Baroque and delicate Rococo style to his works. For jewelry design, Mucha often uses comprehensive materials to demonstrate his personal styles.

For example, one of his works "Bracelet Gold plated"( 1899), he used gold, pearl, and enamel.Enamel is also known as "Cloisonné" [5]. The pursuit and adoration for Mucha's works give us the inspiration , "The pride of a nation is also the pride of the world”. Mucha absorbed Cloisonné into his constant works, by combining different styles of craftmanship, he successfully made Cloisonné more native and popular. Fogyism is a dead end, in order to create a better furture for Cloisonné, innovations are desperately needed.

The achievements of Chinese crafts are not the isolated products. They should be constantly improved based on the origins, thus to meet the contemporary people's aesthetic demand.Currently, the domestic Cloisonné crafts are roughly made because of the market orientation.It requires low cost and rapid productivity.Also their designs are inflexible, superficial, and lack of innovation and creativity. These above reasons result in the difficulty of Cloisonné crafts to integrate into our lives. Therefore, we consider in today's society, there should be some appropriate transformations on Cloisonné to make such skills continuously inherited and adapted to the modern people's lives.

\section{THE INHERITANCE AND DEVELOPMENT OF CLOISONNÉ}

In today's embarrassing situation of the development of Cloisonné, we recognize that the measures to save the predicament should include:
A. Control the cost of Cloisonné handicrafts according to the requirements of the market orientation.

Cost-control is only not about reducing every single cost of the crafts, the focus should be on the quality. For example, reduce the production of large objects,instead, make some small, exquisite goods for daily usage. So it will has certain practicality. And to improve its performance ratio so as to promote the purchase desire of consumers and also meet their demands.

B. Develop the production of Cloisonné jewelry and adopt more exquisite crafts so as to make appropriate choices about pattern innovation.

To let Cloisonné jewelry come into the modern people's lives. In order to adapt to the fast-paced city life, nowadays, on the grounds that most of modern people are endowed with the aesthetic standard- simplicity and fashion, also the same goes for clothing and accessories.Thus, if there is no change or innovation which adapted to classical Cloisonné patterns, and it will be very difficult to be acknowledged by the modern people. So, there should be some trade-offs and certain innovations on the basis of integrating fashion elements on traditional patterns, color collocation of Cloisonné so that it can really integrate into our lives.

\section{The government should provide Cloisonné artists and some factories with preferential policies and intellectual property protection.}

The state can make short-term or long-term investments in Cloisonné crafts according to whether the works are normal goods for sale or collections with artistic value. In the meantime, Cloisonné craft masters can both gain profits and carry on the artistic creation. More importantly, they are no longer influenced by the sales problem, their skills can be inherited accordingly.

\section{Developing new materials can reduce the cost, meanwhile guarantee the quality of Cloisonné crafts.}

The high price of precious metal materials makes people step back easily; also the traditional glaze which is used to make Cloisonné is considerably expensive.However, currently the materials to make Cloisonné on the market are dissatisfactory in quality, so it's necessary to exploit new materials for Cloisonné crafts in order to guarantee its aesthetic value, reduce the cost as well.

In conclusion, inheritance and development are the common propositions of traditional art. Where there is no inheritance, there is no tradition, where there is no development; there is no newborn of the traditional art. And Cloisonné has become a part of the essence of Chinese culture, and its noble identity and long history have been integrated into the Chinese handicraft tradition. However, in the process of inheriting and development, we have to understand that as for the inheritance of culture and crafts should not simply adhere to conventionality , but discard the dross but keep the quintessence,and pursue innovations so as to promote its development .Consequently,Cloisonné crafts can integrate into our daily life and exist in the continuously improving future. 


\section{ACKNOWLEDGMENTS}

The corresponding author of this paper is Yueshan Wang.This paper is supported by the 10th student's techology innovation project of Sichuan Normal University.

\section{REFERENCES:}

[1] Hu Ping. Modern and Inheritance of Traditional Metal Arts and Crafts in the Mainland, Zhejiang Arts and Crafts.2001 (3).

[2] Deng Zhe. On the Color and Style Characteristics and Causes of the Formation of Cloisonne. Popular Literature, 2008 (4).

[3] King Weisi. There is Huge Rise Space for the Price of the Bright Younger Generation of Cloisonne. The Wealth of Wisdom.2008 (4)

[4] Cao Kanglin. Save the Managers of Cloisonne.2005.

[5] Huang Lian. "Wind of the Nature, Place of Dreams" Jewelry Design of the New Art Movement. Shanghai Arts and CraftS.2011 (2).

[6] Wang Zhiqin. Cloisonne Market Makes People Happy and Worry. Chinese New Era. 2013 (10)

[7] Laoshuo. The Fashion Elements of Traditional Cloisonne. Commercial Culture.2008 (7) 